\title{
MAKNA PENDIDIKAN NYANYIAN MASAMPER BAGI MASYARAKAT SANGIHE YANG BERADA DI TATELI MINAHASA
}

\author{
${ }^{1}$ Geraldy F. Telussa, ${ }^{2}$ Markus Wibowo \\ ${ }^{1}$ Mahasiswa Pendidikan Musik Gereja IAKN Manado, ${ }^{2}$ Dosen Musik Gereja IAKN Manado \\ 19adosnandos420@gmail.com, ²wibowomarkus986@gmail.com
}

\begin{abstract}
Abstrak
Penelitian ini merupakan kajian tentang makna pendidikan yang terdapat pada nyanyian Masamper yaitu sebuah nyanyian tradisi masyarakat Sangihe. Adapun metode yang digunakan dalam penelitian ini adalah metode kualitatif, yang merupakan metode penelitian yang berdasarkan pada filsafat postpositivisme. Untuk memaknai nyanyian Masamper maka penelitian ini menggunakan teori analisis wacana yang mana didalam analisis teks sebuah lagu Masamper menggunakan 3 (tiga) aspek yaitu; analisis sintaksis, analisis semantik, dan analisis pragmatik. Berdasarkan analisa data yang dilakukan, dapat dikemukakan bahwa nyanyian masamper adalah nyanyian yang bisa menjadi salah satu sarana untuk berkomunikasi, menyampaikan pesan dan nasihat melalui lagu yang dinyanyikan, dan pesan yang disampaikan bisa dilihat dari lirik lagu yang akan dinyanyikan. Salah satu makna yang dapat disampaikan adalah makna pendidikan. Makna pendidikan yang dapat dikemuakakan dalam makna nyanyian Masamper ini adalah cenderung kepada makna moralitas yang dapat diimplenentasikan dalam kehidupan sehari-hari masyrakat Sangihe yang ada di Tateli.
\end{abstract}

Kata kunci : Makna Pendidikan, nyanyian Masamper

\section{THE MEANING OF THE MASAMPER EDUCATION FOR SANGIHE COMMUNITIES IN MINAHASA TATELI}

\begin{abstract}
This research is a study of the meaning of education found in the Masamper song, a traditional Sangihe song. The method used in this study is a qualitative method, which is a research method based on the philosophy of postpositivism. To interpret Masamper's song, this study uses the theory of discourse analysis which in the text analysis of a Masamper song uses 3 (three) aspects, namely; syntactic analysis, semantic analysis, and pragmatic analysis. Based on the data analysis, it can be stated that the Masamper song is a song that can be a means of communicating, conveying messages and advice through the song being sung, and the message delivered can be seen from the lyrics of the song to be sung. One meaning that can be conveyed is the meaning of education. The meaning of education that can be said in the meaning of Masamper's singing is inclined to the meaning of morality that can be implemented in the daily life of Sangihe people in Tateli.
\end{abstract}

Keywords: The meaning of education, the singing of Masamper

\section{Pendahuluan}

Bagi masyarakat Sangihe, berpantun merupakan tradisi yang unik melalui kemampuan menghafal sebanyak mungkin repertoar pantun untuk digunakan dalam acara "Mebawalase/Mebawalase Kantari", dalam berpantun secara berbalas-balasan antar dua orang atau kelompok. Kemampuan menghafal pantun atau 
Tinggung $^{1}$ (sindiran dalam bentuk tekateki) memang sudah ada di masyarakat Sangihe dan diajarkan secara turun temurun. Pada umumnya dalam berpuisi masyarakat Sangihe mempunyai pantun Tinggung sebagai sastra lisan yang paling tua usianya.

Istilah Mebawalase disepakati untuk digunakan berdasarkan pertimbangan bahwa itu merupakan tradisi lisan seni vokal masyarakat Sangihe dalam bentuk berbalas-balasan antara individu atau kelompok. Istilah Kantari yang berasal dari bahasa Italia cantare, kemudian berubah menjadi Sampere berasal dari bahasa Belanda zangsfeer yang artinya bernyanyi bersama dalam suasana tertentu.

Sejak masuknya Pengaruh Barat, kesenian Mebawalase melahirkan bentuk yang baru yaitu saling berbalas lagu atau Mebawalase Kantari. ${ }^{2}$ Pada zaman dahulu Mebawalase Kantari hanya digelar di acara Pernikahan, acara hajatan, dan juga di perkabungan, dan biasanya lagu yang dinyanyikan harus sesuai dengan konteks yang ada contoh kalau di acara pernikahan lagu yang dinyanyikan harus lagu yang menceritakan tentang kebahagiaan dan juga percintaan, sedangkan kalau di acara perkabungan lagu yang dinyanyikan harus lagu yang menceritakan tentang kesedihan dan juga lagu yang menghibur, begitupun

1 Tinggung merupakan sebuah sindiran dalam bentuk tekateki, tekateki yang dimaksud adalah menebak lagu dan menebak maksud dari isi lagu atau nyanyian yang disampaikan. Wawancara: Jhony Bimbanaung, 14 Maret 2019 dengan lagu yang akan dibawakan di acara hajatan harus sesuai dengan konteks yang ada.

Setelah masa kemerdekaan, kesenian Mebawalase Mesampere ditetapkan sebagai salah satu identitas budaya Sangihe sebagai kesepakatan Sarasehan Daerah Sangihe di Tahuna tahun 1981 yang diprakarsai oleh Bupati Sangihe Talaud Jan Mende. Sejak itu Mebawalase Mesampere diresmikan sebagai ajang lomba untuk melestarikan kesenian itu kepada generasi muda. Kegiatan Mebawalase Mesampere menyebar ke Manado pada tahun 1977 di kampung Tuna. ${ }^{3}$ Dalam perlombaan ada beberapa tema nyanyian yang akan dinyanyikan seperti Tema Pertemuan, Pujian Rohani, Sastra Daerah, Percintaan (Cinta Badani, atau cinta antara pria dan wanita) dan ada juga tema tentang percintaan rohani (tetapi jarang dipakai dalam perlombaan), dan tema yang terakhir adalah perpisahan. Dalam perlombaan ada beberapa aturan dan ketentuan yang dipakai baik dalam bernyanyi, posisi atau variasi barisan, pakaian, durasi bernyanyi dll.

Masamper juga bisa dijadikan salah satu media bagi masyarakat yang ada di daerah Sangihe untuk berkomunikasi dengan cara menyampaikannya melalui lagu-lagu atau puji-pujian dalam bentuk

\footnotetext{
${ }^{2}$ Ganap Victorius, Metagonggong dan Mebawalase Masampere Tradisi Masyarakat Kepulauan Sangihe (Tahuna: 2010)

${ }^{3}$ ibid
} 
nyanyian dengan tujuan menyampaikan pesan-pesan yang hendak disampaikan. Saat ini kesenian Masamper juga ada dan berkembang di salah satu daerah di Sulawesi Utara, yaitu tepatnya di desa Tateli, kabupaten Minahasa. Di desa Tateli kesenian Masamper tetap dipertahankan dan masyarakatnya pun terus melestarikan kesenian masamper. Di daerah ini juga terdapat banyak orang Sangihe yang sudah berdomisili di desa Tateli Kabupaten Minahasa, mereka tetap mempertahankan kesenian mereka, dan sering juga mengadakan perlombaan masamper. Meskipun mereka tinggal di Minahasa namun budaya Sangihe sangat kental dalam masyarakat Tateli keturunan Sangihe. Dengan adanya Masamper ada upaya eksistensi nyanyian tradisi Sangihe yang terus dipertahankan, sehingga Masamper mampu membuat masyarakat Sangihe yang ada di Minahasa terkumpul dan terciptanya persatuan serta mempererat tali persaudaraan dengan mempertahankan dan melestarikan nyanyian masamper.

\section{Masamper Sangihe}

Masyarakat Sangihe merupakan Masyarakat yang menjadikan nyanyian menjadi bagian yang paling penting dalam kehidupan sehari-harinya. Bernyanyi dapat dikatakan sebagai "nafas" bagi warga Sangihe, terbukti dalam setiap aktifitas mereka selalu melakukan nyanyian. Nyanyian tradisional yang menjadi ciri khas masyarakat Sangihe salah satunya adalah
Masamper. Masamper merupakan nyanyian yang tidak asing lagi bagi masyarakat Sangihe, hampir diberbdagai tempat diadakan atau dilaksanakan perlombaan Masamper.

Dahulu masamper hanya digunakan dalam acara-acara tertentu seperti acara pernikahan, hajatan, dan kedukaan, dan lagu yang dibawakan harus sesuai dengan konteks yang ada, seperti dalam acara pernikahan lagu yang digunakan atau dinyanyikan harus lagu yang menceritakan tentang ucapan syukur dan lagu yang menceritakan tentang kebahagiaan, juga tentang kasih dan sayang. Namun kini masamper sudah bisa digunakan dalam ajang perlombaan.

Masyarakat Sangihe seakan tidak pernah lepas dari kesenian Masamper, ini dapat dibuktikan dengan hampir semua masyarakat Sangihe yang merantau khususnya di daerah Minahasa yang sering memperdengarkan Masamper dan juga hampir setiap tahun diadakan perlombaan di Manado yang diikuti oleh masyarakat Sangihe dan bahkan ada yang mengikuti masamper yang bukan dari masyarakat asli Sangihe.

\section{Masamper}

Masamper merupakan nyanyian tradisional masyarakat Sangihe yang tetap dipertahankan. Nyanyian Masamper adalah nyanyian yang dinyanyikan secara bersama-sama dan secara berbalasbalasan. Bernyanyi berbalas-balasan 
dalam kegiatan Masamper dilakukan dengan bernyanyi bersama-sama dan berjalan seperti membentuk sebuah bentuk atau variasi barisan, kemudian salah satu dari anggota atau bisa dikatakan "Pangaha" 4 membawa sebuah benda contohnya seperti bunga untuk dipegang sebagai tanda bahwa lagu itu harus dibalas. Setelah lagu selesai dinyanyikan maka bunga yang tadinya dipegang harus kembali diberikan kepada orang lain sebagai tanda lagu tersebut harus dibalas.

\section{Bentuk Masamper}

Nyanyian masamper merupakan nyanyian yang bisa dikategorikan nyanyian rakyat "folksongs" ${ }^{6}$. dikatakan nyanyian rakyat karena dalam nyanyian Masamper terdapat makna sosial dan pesan yang terkandung dalam lirik lagu.

Bentuk dari nyanyian Masamper adalah berbentuk Pantun $A B, A B$, yaitu yang baris pertama sama dengan baris ketiga (sama-sama a), kemudian baris yang kedua sama dengan baris keempat (bersajak b).

Contoh lagu:

Daluaseku natinalung

Suendumang ikekaralo

Leadate sipungu tulumang

Kapiane nematiku lawo

\footnotetext{
${ }^{4}$ Pangaha adalah sebutan untuk pemimpin barisan dalam bernyanyi Masamper, Wawancara: Korneles B. Durikase, 16 Maret 2019

${ }^{5}$ Folksong adalah nyanyian vokal atau lagu rakyat yang dinyanyikan. Banoe Pono,Kamus Musik,kanisius,Jogjakarta,2003,h.150
}

\section{Instrumen dalam Masamper}

Instrumen dalam nyanyian Masamper jarang dipakai. Jika saat dalam latihan untuk persiapan lomba biasanya dipakai instrumen seperti gitar agar mempermudah bagi anggota Masamper mempelajari lirik lagu dan melodi serta ketukan dari lagu yang akan dinyanyikan.

Namun ketika dalam bernyanyi Masamper, instrumen tersebut tidak digunakan, karena masyarakat Sangihe hanya bernyanyi Masamper dengan tidak menggunakan instrumen.

\section{Cara Bernyanyi dalam Masamper}

Kesenian masamper merupakan ungkapan hati nurani yang memiliki nilai religius dan juga nilai moral. Selain itu, masamper juga berisi ajakan, ajaran moral juga tata cara pergaulan dalam hidup bermasyarakat yang tersirat dalam lirik lagu. Cara bernyanyi dalam nyanyian Masamper adalah bernyanyi bersamasama dan berbalas-balasan/ responsorial, kemudian bernyanyi dengan empat suara, sopran, alto, tenor dan bass. Jumlah anggota dalam bernyanyi Masamper di perlombaan minimal 25 orang dan dibagi dalam beberapa kelompok suara.

\section{Simbol Dalam Nyanyian Masamper}

a. Simbol Gerakan

\footnotetext{
6 Meyltsan Maragani,"Nilai-nilai yang tertanam pada masyarakat dalam kegiatan masamper di desa Laonggo",catharsis journal of arts education,prodi pendidikan seni, UNNES,2016
} 
Simbol gerakan dalam kesenian masamper, sebenarnya hanya selingan saja tidak menentu untuk dipakai dalam kesenian masamper. Akan tetapi dewasa ini sudah banyak yang menggunakan gerakan dalam membawakan kesenian ini. Gerakan dalam masamper sebenarnya hanya pelengkap/ pendukung barisanbarisan pada umumnya. Pada umumnya gerakan disesuaikan dengan variasi barisan dipentas. Terbanyak adalah gerakan tangan sambil menari disamping badan sampai ke atas kepala, sewaktuwaktu diletakan di pinggang., demikian gerakan badan bisa miring kekiri dan miring kekanan sampai posisi jongkok. Gerakan dalam masamper hanya untuk mengkombinasikan kelompok dalam membawakan lagu menambah nilai ungkapan makna penampilan. Makna gerakan sebenarnya menggambarkan tentang kelemah-lembutan ketulusan tubuh disamping ekspresi kegembiraan dan kesedihan. Dan gerakan-gerakan dalam setiap acara tergantung ekspresi dari setiap anggota, kecuali gerakan dalam masamper yang diperlombakan, setiap gerakan harus mengikuti arahan dari pemimpin kelompok. ${ }^{7}$

\section{b. Simbol Atribut / Pakaian}

Busana yang dipakai anggota masamper hanya sederhana, jika dalam acara syukuran hanya menggunakan

\footnotetext{
7 L. makasenda, Journal"Acta Diumai" Volume III. No.3. Tahun 2014
}

busana bebas, akan tetapi jika dalam perlombaan harus memakai seragam/pakaian adat Sangihe. Penggunaan atribut itu wajib, karena merupakan kebutuhan universal bagi masamper untuk tampil pada suatu hajatan. Dan hal itu mengisi tanda bahwa membedakan tiap kelompok masamper yang satu dengan yang lain. Artinya bahwa atribut dan kostum itu menjadi penampilan visual dari setiap kelompok masamper untuk mengikuti lomba dan festival.

Yang menjadi atribut dari masamper perlombaan adalah:

1. Baniang, adalah baju adat dari kepulauan Sangihe. Tandanya masyarakat masih mencintai dan menghargai budaya dari daerah asal mereka meskipun sudah lama dan menetap di daerah lain.

2. Paporong, adalah topi adat dari kepulauan Sangihe. Dalam setiap penampilan pemimpin dan anggota harus menggunakan paporong yang memberikan tanda antara pemimpin dan anggota kelompok. Yang menjadi tanda adalah jika kerucut kedepan adalah pemimpin kelompok masamper, dan jika kerucut ke belakang adalah anggota-anggota dari kelompok masamper. 
3. Papehe, adalah ikat pinggang yang berlaku untuk laki-laki, yang menandakan kekuatan dan pelindung bagi anggota keluarga (bagi yang sudah menikah).

4. Salendang, jika papehe berlaku untuk laki-laki maka selendang berlaku untuk perempuan, dan jika gantungan dari kanan ke kiri sebagai symbol perempuan yang belum menikah sedangkan dari kiri ke kanan adalah perempuan yang sudah menikah. ${ }^{8}$

\section{Makna Nyanyian Masamper}

Penelitian ini akan menganalisis makna pendidikan nyanyian Masamper. Teori yang digunakan dalam menganalisis nyanyian Masamper adalah teori analisis wacana. Analisis wacana merupakan suatu kajian yang meneliti atau menganalisis bahasa yang digunakan secara alamiah, baik dalam bentuk tulis maupun lisan terhadap para pengguna sebagai elemen masyarakat. Nunan mengatakan analisis wacana merupakan studi mengenaipenggunaan bahasa yang memiliki tujuan untuk menunjukkan dan menginterpretasikan adanya hubungan antara tatanan atau pola-pola dengan tujuan yang diekspresikan melalui unit kebahasaan tersebut. ${ }^{9}$ Dalam teori ini

\footnotetext{
${ }^{8}$ L. makasenda, Journal"Acta Diumai" Volume III. No.3. Tahun 2014

9 Nunan, David. 1993. Introducing Discourse Analysis. London: Penguin Book
}

terdapat beberapa aspek diantaranya melibatkan analisis sintaksis, semantik, pragmatik. Adapun yang dimaksud dengan ketiga teori tersebut adalah:

\section{a. Sintaksis}

Kata sintaksis berasal dari bahasa Yunani, yaitu sun yang berarti "dengan" dan kata tattein yang berarti "menempatkan". Jadi, secara etimologi berarti: menempatkan bersama-sama kata-kata menjadi kelompok kata atau kalimat. $^{10}$ Manaf menjelaskan bahwa sintaksis adalah cabang linguistik yang membahas struktur internal kalimat. Struktur internal kalimat yang dibahas adalah frasa, klausa, dan kalimat. ${ }^{11}$ Berdasarkan pernyataan tersebut maka dapat disimpulkan bahwa sintaksis merupakan ilmu tata kalimat yang membahas susunan kalimat dari suatu unsur bahasa yang menentukan fungsi, kategori, peran kalimat tersebut.

b. Semantik

Kata semantik dalam bahasa Indonesia (inggris: semantic) diturunkan dari kata bahasa Yunani kuno sema (bentuk nominal yang berarti "tanda" atau "melambangkan". Yang dimaksud dengan tanda atau lambing disini sebagai padanan kata "sema" itu adalah tanda linguistik

10 W.budayawati, "sintaksis Tata Kalimat Bahasa Indonesia" (paper presented at Universitas Pendidikan Indonesia, Sumedang,2011)

11 Manaf, Ngusman Abdul, 2009. Sintaksis: Teori dan terapannya dalam Bahasa Indonesia. Padang: sukabina Press. 
(Prancis: signe linguistique) Ferdinand dalam Abdul mengatakan bahwa tanda linguistik itu terdiri dari komponen penanda (Prancis: signife) yang berwujud bunyi, dan komponen petanda yang berwujud konsep atau makna. ${ }^{12}$

\section{c. Pragmatik}

Menurut Tarigan pragmatik merupakan telaah umum mengenai bagaimana caranya konteks mempengaruhi cara seseorang menafsirkan kalimat. ${ }^{13}$ Pendapat lainnya disampaikan Leech bahwa seseorang tidak dapat mengerti benar-benar sifat bahasa bila tidak mengerti pragmatik, yaitu bagaimana bahasa digunakan dalam komunikasi. ${ }^{14}$ Pernyataan ini menunjukan bahwa pragmatik tidak lepas dari penggunaan bahasa. Dengan demikian maka pragmatik merupakan telaah mengenai kemampuan pemakai bahasa yang menghubungkan serta menyerasikan kalimat dan konteks.

Di dalam nyanyian Masamper terdapat pesan-pesan yang disampaikan yang dibawakan dalam bentuk nyanyian, pesanpesan yang disampaikan ada bermacammacam sesuai dengan tema lagu yang ada dan sesuai dengan konteks yang ada. Pesan yang disampaikan juga mengandung makna, makna yang

\footnotetext{
12 Modul 1 Abdul Chaer,"Makna dan Semantik" 2012 ha.4. Jakarta:penerbit salemba.

13 Tarigan,Tanjung,(1985), “prinsip-prinsip pragmatik" ha.34,Surabaya:andi press.
}

terkandung contohnya adalah makna sosial. Makna sosial yang terdapat contohnya melalui lirik lagu yang disampaikan adalah nyanyian yang bercerita kedukaan, maka melalui lirik lagu tersebut bisa saling menghibur dan memberi penguatan, sehingga melalui nyanyian Masamper bisa menyampaikan maksud dan pesan serta mengandung makna yang tersirat.

Makna sosial yang dimaksud adalah terjalinnya hubungan atau relasi antara satu dengan yang lainnya sehingga bisa saling menopang, menghargai, membantu dan lain sebagainya. Maka melalui nyanyian Masamper, masyarakat bisa menjadikan nyanyian Masamper sebagai alat komunikasi untuk saling menyampaikan pesan dan makna yang ingin disampaikan.

\section{Metode}

Metode yang dipakai dalam penelitian ini adalah kualitatif yaitu metode penelitian yang berdasarkan pada filsafat postpositivisme, digunakan untuk meneliti pada kondisi subjek ilmiah, (sebagai lawannya adalah eksperimen) dimana peneliti adalah sebagai instrument kunci, pengambilan sempel sumber data dilakukan secara purposive dan snowbaal, teknik pengumpulan dengan trianggulasi

\footnotetext{
14 Leech, Geoffrey, (1976), Semantik 1 and 2, Utrecht Antwerp: Uitgevery Het Spectrum.
} 
(gabungan), analisis data bersifat induktif/kualitatif, dan hasil penelitian kualitatif lebih menekankan makna daripada generalisasi. ${ }^{15}$ Penelitian ini mengkaji makna dari suatu peristiwa dan situasi tertentu yang merujuk kepada makna dari gejala, atau fakta dan realita yang sedang terjadi dalam sebuah pertunjukan. Penelitian ini dilakukan pada bulan April hingga Juli 2019.

\section{Hasil dan Pembahasan}

\section{Analisis Teks}

a. Analisis Sintaksis,

Terdapat makna pendidikan dilihat secara Analisis Sintaksis, contoh dalam tema lagu perjuangan berikut:

Jauh seb'lum pertempuran 10 November Terjadilah penyerbuan dihotel oranye Bendera merah putih biru terpampang di hotel Orange

Waktu nipon namanya yamato

Membangkitkan amarah rakyat di Surabaya

Teriak takut bahaya brani menembus penantang

Seorang pemuda akhirnya berhasil

Naik tiang segitiga warna

Birunya dirobek tinggal merah putih

Dinaikan berkibarlah dengan mulia.

Dalam Analisis Sintaksis bisa dilihat bahwa makna pendidikan yang terdapat didalamnya ialah melalui pengkalimatan lagu, dimana di dalam lagu terdapat makna pendidikan yang menceritakan tentang sejarah bangsa Indonesia yang terjadi

15 Dr Sugiyono, Metode Penelitian (bandung: alfabeta,2012),h.15 pada awal sebelum terjadinya kemerdekaan, jadi dengan adanya cerita sejarah yang dituangkan dalam lagu tersebut, bisa membuat orang-orang yang mendengarkan ataupun bagi pelajar dapat mengetahui sejarah tersebut.

\section{Analisis Semantik}

Makna pendidikan dapat dilihat secara Analisis Semantik. Contoh dalam kutipan lagu dalam tema Sastra berikut:

Tentirong kalimonane niriadi kere I tetimona Maning lampaeng tawe hunduge Kai naung mang sumonara Nanarang suwanalang pengangendungang Piabe timole bihingang-bihingang Tawe apa kinawulenang Ore mambeng madareso su endumang Hakieweng pia u nahengke tembonang Ore nakapeti biahe Nakasombo katanaeng Nakawewe banuane Ku tanude pakapia Abe sarang malei Suri be sunaung satia Tetau kebi ene kai bou batu lei.

Terjemahan dari lagu Batu Lei:

Ajaran yang pertama terjadi seperti yang diharapkan

Walaupun beralaskan yang tak semestinya Tapi tujuan yang utama tetap pada apa yang akan dilakukan

Terbiasa di tempat menuntut ilmu

Mengikuti apa yang diajarkan

Tidak ada yang terlupakan

Namun tetap tersimpan dalam ingatan

Sehingga ada yang menjadi seorang pemimpin

Dan dapat membangun kehidupan yang layak

Mengharumkan tempat asalnya 
Dan membanggakan tempat asalnya

Oleh sebab itu peliharalah dengan baik Jangan sampai tersia-siakan

Tetap simpan dalam ingatan

Karena semuanya itu berasal dari batu lei.

Dalam Analisis Semantik makna pendidikan yang terdapat dalam lagu tersebut. Dimana lagu tersebut menceritakan bahwa sejarah orang-orang Sangihe menulis dan belajar di sekolah menggunakan "Batu Lei". Batu Lei ini adalah sebuah batu yang digunakan untuk menulis, sebelum mereka mengenal buku dan alat tulis yang sekarang digunakan. Dan alat tulis yang digunakan namanya adalah grep. ${ }^{16}$ Pada zaman dahulu anakanak yang sekolah menulis di batu lei pelajaran yang mereka pelajari pada hari itu, sesudah selesai belajar mereka menghapus semua pelajaran yang mereka dapati hari itu dengan menggunakan air, karena besok mereka akan menggunakan kembali batu lei tersebut. Jadi pelajaran yang mereka dapati harus betul-betul di ingat dan dipahami, karena sudah tidak ada lagi yang tersimpan karena sudah terhapus. Dalam lagu ini diceritakan bahwa banyak orang-orang yang sukses walaupun hanya menggunakan batu lei. Jadi lagu ini bisa menjadi sebuah pelajaran bagi generasi muda sekarang bahwa kita harus tetap semangat dalam menggapai cita-cita. ${ }^{17}$

\footnotetext{
${ }^{16}$ Grep merupakan sebuah alat tulis yang dibentuk dari batu hingga menyerupai kapur dan tempat untuk menulis adalah batu lei, serta untuk
}

\section{Analisis Pragmatik}

Analisis pragmatik ini menyatakan bahwa contoh dan makna lagu yang dinyanyikan sesuai dengan konteks yang ada. Seperti contoh dalam lagu masamper yang bertema Pujian. Lagu ini diciptakan untuk mengingatkan kepada orang-orang yang percaya kepada Tuhan untuk tetap percaya kepda Tuhan, walaupun banyak tawaran-tawaran dunia yang menawari sesuatu yang tidak baik tapi Tuhan tetap menjadi tempat berteduh dan tempat berlindung. Contoh dalam lagu berikut:
Mahi pakarariahi apang tau sahani Daleng pakawawahani mesamala si Umbolangi
Kaihi koaneng mamirahi sarang daleng dalaki
Dunia mambeng masaki kumbahang makapeto karaki
Mawu kai pekakelungang, su tempong peselihang
I Sie tawe menanentang, kumbahang ghumenggang
Mawu mang dingang kate
pakalaamumang
Mawu pesasirungang simbulu tulumang.

Terjemahan :

Marilah bersiap hai umat Tuhan

Berjalan dengan berani memuji nama

Tuhan

Kiri dan kanan membujuk ke jalan yang jahat

Dunia seakan sakit, janganlah sampai gagal mencapai tujuan

Tuhan tempat perlindungan disetiap waktu la tak pernah meninggalkan, dan janganlah kau kuatir Tuhan kan selalu besertamu tetaplah berlaku baik

menghapus tulisan di batu tersebut menggunakan air. Wawancara: Korneles Durikase, 8 Juni 2019

${ }^{17}$ Korneles Durikase, wawancara 8 Juni 2019 
Tuhan tempat perteduhan sumber kehidupan

Dari hasil penelitian diperoleh makna pendidikan dari nyanyian masamper. Adapun makna pendidikan yang dimaksud adalah:

- Pendidikan Karakter, pendidikan karakter merupakan suatu bentuk kegiatan yang dilakukan masyarakat yang di dalamnya terdapat suatu tindakan yang mendidik. Seperti yang dikemukakan oleh Doni Koesoemo pendidikan karakter menjadi sebuah pegangan tujuan agar setiap pribadi semakin menghayati individualitasnya, mampu menggapai kebebasan yang dimilikinya, sehingga ia dapat semakin bertumbuh sebagai pribadi maupun sebagai warga Negara yang bebas dan bertanggung jawab, bahkan sampai pada tingkat tanggung jawab moral integral atas kebersamaan hidup dengan yang lain di dalam dunia. $^{18}$ Pendidikan karakter yang terdapat dalam masamper adalah suatu kegiatan seperti gotong royong serta kerja sama yang terbentuk yang dilakukan berulang-ulang oleh masyarakat.

- Pendidikan pengetahuan umum, pendidikan tentang pengetahuan umum pada nyanyian masamper

18 Doni Koesoema, Pendidikan Karakter: Strategi mendidik anak di zaman global Jakarta:Grasindo, 2010. adalah dalam sebuah lirik lagu dapat diceiritakan sebuah cerita yang terjadi pada masa yang lampau, seperti dalam nyanyian masamper yang bertema perjuangan, dimana dalam lagu ini dapat menceritakan kembali peristiwa-peristiwa perjuangan yang dilakukan pahlawan-pahlawan pada masa yang lampau.

Pendidikan Religi, dalam nyanyian masamper terdapat pendidikan yang bersifat religi, dimana dalam nyanyian ini terdapat tema Pujian yang bermaksud menyampaikan rasa syukur dan pujian kepada Tuhan karena telah memelihara kehidupan manusia. Jadi lewat nyanyian masamper bisa menyampaikan rasa syukur serta pujian kepada Tuhan.

Masamper tidak hanya sebatas nyanyian yang bersifat hiburan saja tetapi banyak nilai-nilai yang terkandung didalamnya, nilai itu dapat merujuk kepada kehidupan sosial, religi, maupun pendidikan. $^{19}$

\section{Analisis Musik}

Secara musikal nyanyian Masamper dapat dianalisis melalui unsur-unsur musiknya. yang terkandung di dalamnya seperti Ritme, Melodi, Interval, Harmoni, dan Bentuk lagu yang semua itu terbentuk

\footnotetext{
${ }^{19}$ Korneles Durikase, Wawancara, Juni 2019
} 
sehingga menjadi sebuah kesatuan yang utuh.

Berikut ini merupakan unsur-unsur musik yang terdapat dalam nyanyian Masamper yang mencerminkan daerah Sangihe:

\section{a. Ritme}

Ritme adalah unsur paling dasar di dalam musik, dengan ritme, gerak irama musik dapat diikuti. Dalam nyanyian Masamper seperti pada lagu "Daluaseku Natinalung", Daluaseku Natinalung

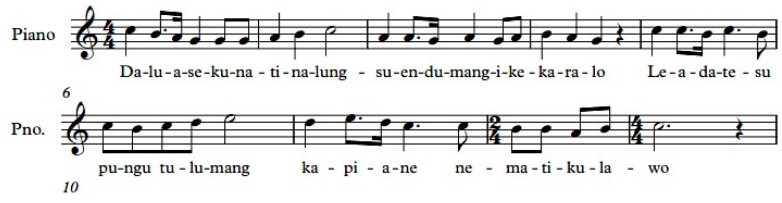

Gambar 1. Pergerakan Ritme

Pergerakan ritme cenderung berirama Mars yang menggunakan kombinasi not seperdelapan dan seperenambelas, yang memberikan langkah cepat dan tergesa-gesa. Dikatakan tergesa-gesa karena lagu yang dibawakan dinyanyikan secara berbalasbalasan, jadi nyanyian Masamper ciri khasnya cenderung cepat atau berirama mars.

b. Melodi

Melodi merupakan bagian yang paling penting dalam suatu musik, karena melodi merupakan bagian yang paling menonjol dalam sebuah musik. Seperti pada lagu berikut:

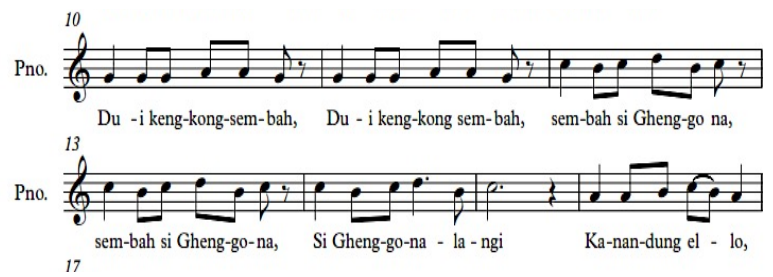

Gambar 2. Pergerakan Melodi

Melodi dalam nyanyian Masamper cenderung bersifat bersemangat, karena lirik-lirik yang disampaikan didalamnya merupakan sebuah lirik yang bersifat saling membangun, saling mendukung, bahkan saling mengingatkan sesama manusia, bahkan dengan melodi yang cenderung bersifat bersemangat ini menjadi salah satu cerminan masyarakat Sangihe yang selalu semangat dan tak pantang menyerah dalam menjalani kehidupan.

c. Interval

Interval adalah jarak antara dua nada. Dalam musik, interval menimbulkan suasana tertentu; misalnya, interval terts mmayor (do-mi; fa-la) memberikan kesan 'maskulin', cerah; interval terts minor (misol; lla-do) memberikan kesan 'feminim', redup. Selain itu ada interval Konsonan (misalnya terts mayor, terts minor) yang memberikan kesan stabil, nyaman dan tenang yang berlawanan dengan interval disonan (misalnya sekonda mayor [do- re, re-mi]; sekonda minor [mi-fa, si-do]) yang 
memberikan kesan labil, gelisah dan galau. $^{20}$

Interval nyanyian masamper sebagian menggunakan interval pendek karena menghasilkan bunyi yang terkesan lebih tenang, sedangkan ada juga yang menggunakan interval panjang yang menghasilkan bunyi yang terkesan bersemangat.

d. Harmoni

Harmoni adalah bunyi tiga nada atau lebih secara bersama-sama. Harmoni dalam sebuah nyanyian sangat penting, karena menimbulkan suasana yang indah. Masyarakat daerah Sangihe sering mengadakan perlombaan masamper, sehingga lewat perlombaan itu ada poinpoin yang di dinilai dan salah satunya adalah harmoni atau keselarasan nada yang dinyanyikan oleh kelompok masamper.

\section{e. Bentuk lagu}

Dalam istilah musik, bentuk lagu merupakan kerangka. Kalimat-kalimat musik dapat disusun dengan memakai bermacam-macam bentuk. Bentuk yang paling banyak dipakai adalah bentuk lagu (Liedform). Artinya: bentuk ini memperlihatkan suatu kesatuan utuh dari satu atau beberapa kalimat dengan

20 Markus Wibowo, Tesis "Makna Nyanyian Ma'kaaruyen Dalam Kehidupan Masyarakat Minahasa", Program Studi Penciptaan dan Pengkajian Seni Minat Studi Pengkajian Seni Musik penutup yang meyakinkan. ${ }^{21}$ Menurut jumlah kalimat, maka dibedakan:

1. Bentuk lagu satu bagian: dengan satu kalimat saja;

2. Bentuk lagu dua bagian: dengan dua kalimat yang berlainan

3. Bentuk lagu tiga bagian: dengan tiga kalimat yang berlainan

Salah satu lagu Masamper yang akan di analisa adalah lagu yang yang bertema Pujian, yang berjudul “ I Ghenggona Langi”

1. Gerakan melodi pada lagu ini berhenti pada tonika "do" yaitu solfa-mi-re-do (5-4-3-2-1).

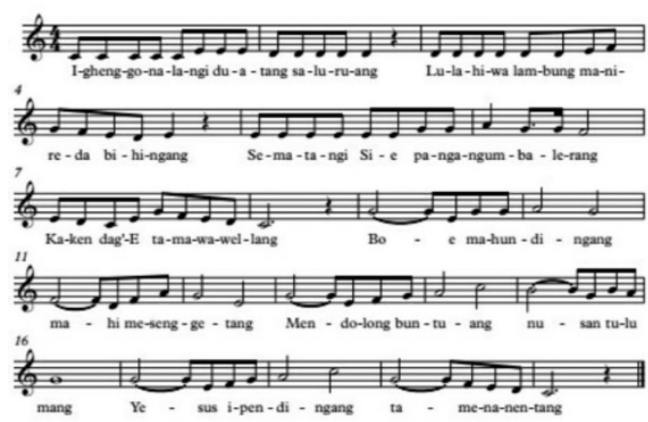

Gambar 3. Analisis Gerakan Melodi berhenti di Tonika Do

2. Gerakan melodi pada "I Ghenggonalangi" ini banyak bergerak melangkah. Kemudian lagu I Ghenggonalangi ini memiliki interval yang cenderung

Nusantara, Institut Seni Indonesia (ISI) Surakarta, 2016

21 Ilmu bentuk musik, Yogyakarta: Karl-Edmund Prier SJ, 2015, cetakan kelima, hal 5 


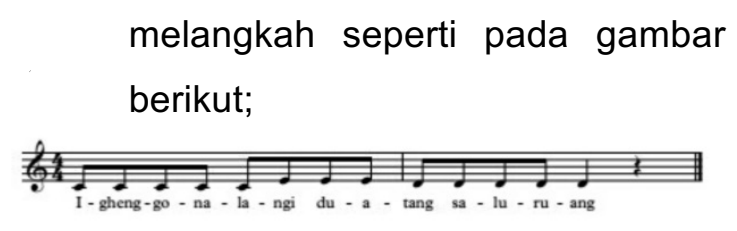

Gambar 4. Analisis gerakan interval lagu I Ghenggonalangi

Pergerakan interval pada lagu ini ada yang bergerak melangkah dan melompat, tapi lompatan interval lagu ini hanya bergerak dari 1-3, sedangkan bergerak melangkah dari 3-2, seperti pada gambar di atas.

Kemudian bentuk lagu I Ghenggonalangi ini memiliki bentuk lagu 2 bagian atau Binary Form yaitu A dan B;

Bentuk lagu bagian A pada lagu ini yang diberi garis warna merah, sedangkan bagian $B$ di beri garis warna hijau.

Lagu "I Ghenggona Langi" ini merupakan lagu bertema Pujian yang biasanya dinyanyikan oleh anggota Masamper. Lagu ini merupakan lagu yang memiliki bentuk lagu Binary Form (Bentuk lagu yang terdiri atas dua bagian).

\begin{tabular}{|c|l|}
\hline Birama & Bagian \\
\hline $1-2$ & Frase Anteseden \\
\hline $3-4$ & Frase Konsekuen \\
\hline $5-6$ & Frase Anteseden \\
\hline $7-8$ & Frase Konsekuen \\
\hline $9-10$ & Frase Anteseden \\
\hline $11-12$ & Frase Konsekuen \\
\hline $13-14$ & Frase Anteseden \\
\hline $15-16$ & Frase Konsekuen \\
\hline $17-18$ & Frase Anteseden \\
\hline
\end{tabular}

\begin{tabular}{|c|c|}
\hline $19-20$ & Frase Konsekuen \\
\hline $1-8$ & 1 Periode \\
\hline $9-20$ & 1 Periode \\
\hline
\end{tabular}

Tabel 1. Analisa musik lagu I Ghenggona

$$
\text { Langi }
$$

Lagu ini bentuk lagu dua bagian yaitu tema $A$ dan $B$, dengan tema $A\left(a, a^{\prime}\right)$ dan tema B.

Akord yang digunakan dalam lagu ini adalah akord tonika, subdominan, dan dominan.

\section{Kesimpulan}

Dari hasil penelitian yang dilakukan, peneliti mengambil kesimpulan bahwa lagu yang dinyanyikan oleh anggota masamper memiliki makna berupa makna pendidikan, religi, dan sosial yang disampaikan untuk orang-orang.

Dalam penelitian ini juga ditemukan bahwa lagu juga menjadi salah satu sarana untuk berkomunikasi. Setiap tema lagu dari nyanyian masamper ada pesan-pesan yang disampaikan melalui lirik lagu tersebut.

\section{Kepustakaan}

Abdul, N Manaf, (2009) Sintaksis: Teori dan terapannya dalam Bahasa Indonesia. Padang: Sukabina Press.

Banoe Pono, (2003) Kamus Musik,kanisius, (Jogjakarta: 2003), Folksong adalah nyanyian vokal atau lagu rakyat yang dinyanyikan.

Budayawati (2011), "sintaksis Tata Kalimat Bahasa Indonesia" (paper presented at Universitas Pendidikan Indonesia, Sumedang. 
Edmund Karl (2015), IImu Bentuk Musik, Yogyakarta: cetakan kelima.

Ganap Victorius, (2010), Metagonggong dan Mebawalase Masampere Tradisi Masyarakat Kepulauan Sangihe,Tahuna.

Makasenda (2014), Journal"Acta Diumai" Volume III. No.3.

Maragani, Meyltsan (2016), Nilai-nilai yang tertanam pada masyarakat dalam kegiatan masamper di desa Laonggo", catharsis journal of arts education,prodi pendidikan seni, UNNES.

Nunan, David. (1993). Introducing Discourse Analysis. London: Penguin Book.

Sugiyono (2012), Metode Penelitian Bandung: Alfabeta.

------------, Metode penelitian Kuantitatif, kualitatif dan R\&D.

Wibowo, Markus (2016), Tesis "Makna Nyanyian Ma'kaaruyen Dalam Kehidupan Masyarakat Minahasa", Program Studi Penciptaan dan Pengkajian Seni Minat Studi Pengkajian Seni Musik Nusantara, Institut Seni Indonesia (ISI) Surakarta. 